\title{
4-Aminopiperidine Derivatives as a New Class of Potent Cognition Enhancing Drugs
}

\author{
Dina Manetti, ${ }^{\mathrm{a}}$ Elisabetta Martini, ${ }^{\mathrm{a}}$ Carla Ghelardini, ${ }^{\mathrm{b}}$ Silvia Dei, ${ }^{\mathrm{a}}$ Nicoletta Galeotti, ${ }^{\mathrm{b}}$

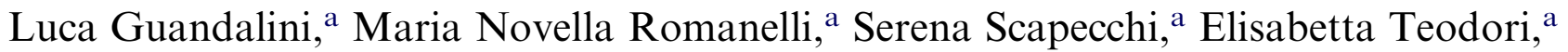 \\ Alessandro Bartolini ${ }^{\mathrm{b}}$ and Fulvio Gualtieri ${ }^{\mathrm{a}, *}$ \\ ${ }^{a}$ Dipartimento di Scienze Farmaceutiche, Università di Firenze, Via G. Capponi 9, I-50121 Firenze, Italy \\ ${ }^{\mathrm{b}}$ Dipartimento di Farmacologia Preclinica e Clinica, Università di Firenze, Viale G. Pieraccini 6, I-50139 Firenze, Italy
}

Received 15 January 2003; revised 31 March 2003; accepted 24 April 2003

\begin{abstract}
Extrusion of one of the nitrogens of the piperazine ring of potent nootropic drugs previously described gave 4-aminopiperidine analogues that maintained high cognition enhancing activity in the mouse passive avoidance test. One of the new compounds $(9$, active at $0.01 \mathrm{mg} / \mathrm{kg}$ ip) may represent a new lead for the development of cognition enhancers useful to treat the cognitive deficit produced by neurodegenerative pathologies like Alzheimer's disease.

(C) 2003 Elsevier Science Ltd. All rights reserved.
\end{abstract}

Cognitive dysfunction is one of the main symptoms accompanying ageing, stroke, head injury and neurodegenerative diseases like Alzheimer's disease. Cognition enhancers, ${ }^{1}$ often referred to as nootropics, can be defined as drugs able to facilitate attentional abilities and acquisition, storage and retrieval of information, and to attenuate the impairment of cognitive functions associated with age and age-related pathologies. ${ }^{2}$ By definition, this class of drugs improves declining of cognitive functions but does not change the rate of progression of neurodegeneration. ${ }^{3}$

Recently, we described a new class of compounds with a 1,4-diazabicyclo[4.3.0]nonan-9-one structure ${ }^{4}$ (Chart 1) that showed a very potent cognition enhancing activity on mouse passive avoidance assay. These compounds were related to the family of piracetam-like nootropics ${ }^{1,5-7}$ by the presence of the 2-pyrrolidinone ring. However, high activity was maintained when the 2-pyrrolidinone ring was opened to give the corresponding piperazine derivatives ${ }^{8}$ (Chart 1), suggesting that in this class of compounds the 2-oxopyrrolidine moiety is not critical for pharmacological action. Both series of compounds were effective also in other behavioural tests such as social learning and Morris water maze. ${ }^{8-10}$

*Corresponding author. Tel.: +39-05527-57295; fax: +39-055240776; e-mail: fulvio.gualtieri@unifi.it
Continuing to explore structure-activity relationships in the series of piperazine compounds, we have designed a new series of compounds carrying a 4-aminopiperidine ring. Formally, they can be considered analogues where one of the nitrogen atoms of piperazine has been moved out of the six-member cycle (Chart 2). Besides the side chains that were present in the leads DM232 and DM235, we have added the isopropylsulfonyl group, present in a series of compounds active as allosteric modulators of AMPA receptor. ${ }^{11,12}$ As a matter of fact, an ongoing research aimed to define the mechanism of action of DM232, DM235 and related compounds seems to suggest the involvement of AMPA receptors. (C. Ghelardini, personal communication).

Compounds 5, 6, 11 and 12 have been synthesised as shown in Scheme 1. 1-Acetyl-4-piperidone and 1-benzoyl-4-piperidone, commercially available, and 1-propionyl-4-piperidone (17), obtained from 4-piperidone monohydrate hydrochloride with propionyl chloride, were transformed in $\mathbf{1 8 - 2 0}$ by reductive alkylation with benzylamine, titanium(IV) isopropoxide and sodium cyanoborohydride. ${ }^{13}$ The compounds were then hydrogenated ${ }^{14}$ to obtain 21-23. Compound $\mathbf{2 3}^{15}$ was treated with acetyl or propionyl chloride to obtain 5 and $\mathbf{6}$ respectively, while $\mathbf{2 1}^{16}$ and $\mathbf{2 2}$ were treated with 4-fluorobenzenesulfonyl chloride to give $11^{17}$ and 12. 
<smiles>O=C1CCC2CN(S(=O)(=O)c3ccc(F)cc3)CCN12</smiles>

DM 232 (Unifiram)

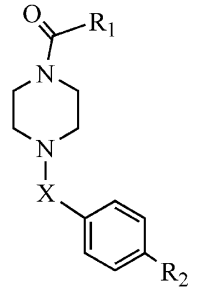

$\mathrm{R}_{1}=\mathrm{CH}_{3} ; \mathrm{X}=\mathrm{CO} ; \mathrm{R}_{2}=\mathrm{H} \quad \mathbf{1}$

$\mathrm{R}_{1}=\mathrm{C}_{2} \mathrm{H}_{5} ; \mathrm{X}=\mathrm{CO} ; \mathrm{R}_{2}=\mathrm{H} \quad 2$ (DM 235; Sunifiram)

$\mathrm{R}_{1}=\mathrm{CH}_{3} ; \mathrm{X}=\mathrm{SO}_{2} ; \mathrm{R}_{2}=\mathrm{F} \quad 3$

$\mathrm{R}_{1}=\mathrm{C}_{2} \mathrm{H}_{5} ; \mathrm{X}=\mathrm{SO}_{2} ; \mathrm{R}_{2}=\mathrm{F} \quad 4$
Chart 1.

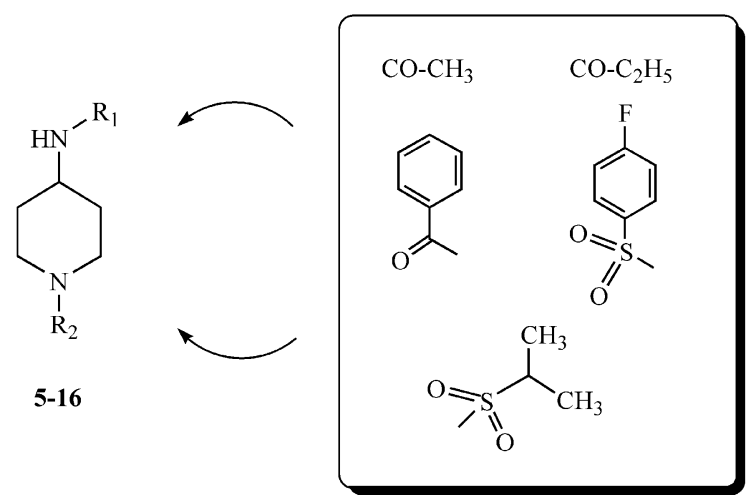

Chart 2.

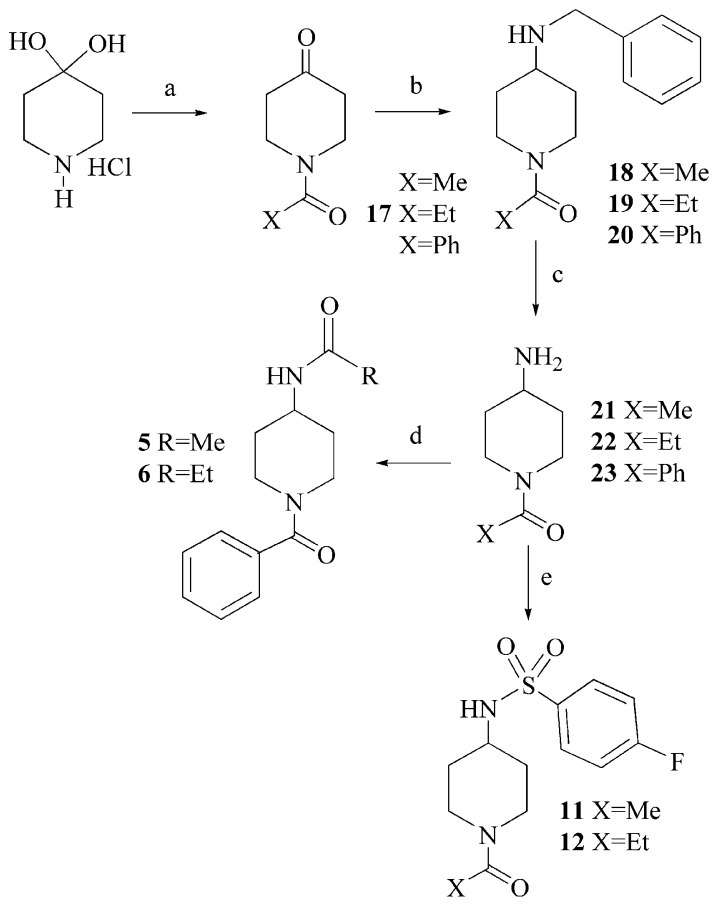

Scheme 1. (a) $\mathrm{CH}_{3} \mathrm{CH}_{2} \mathrm{COCl}, \mathrm{K}_{2} \mathrm{CO}_{3}, \mathrm{CHCl}_{2} 60^{\circ} \mathrm{C}: 17,72 \%$; (b) benzylamine, $(i \mathrm{PrO})_{4} \mathrm{Ti}, \mathrm{NaBH}_{3} \mathrm{CN}, \mathrm{EtOH}: \mathbf{1 8}, 85 \%, \mathbf{1 9}, 68 \%, \mathbf{2 0}$, 26\%; (c) $\mathrm{HCOONH}_{4}, \mathrm{Pd} / \mathrm{C} \mathrm{10 \%}$, MeOH: 21, 74\%, 22, 97\%, 23, 75\%; (d) $\mathrm{CH}_{3} \mathrm{COCl}, \mathrm{NaHCO}_{3}, \mathrm{CHCl}_{3}: \mathbf{5}, 45 \%, \mathrm{CH}_{3} \mathrm{CH}_{2} \mathrm{COCl}, \mathrm{N}(\mathrm{Et})_{3}$, $\mathrm{CHCl}_{3}$ : 6, 94\%; (e) 4-F-benzenesulfonyl chloride, $\mathrm{N}(\mathrm{Et})_{3}, \mathrm{CH}_{3} \mathrm{CN}: \mathbf{1 1}$, $86 \%, \mathbf{1 2}, 82 \%$.
The synthetic pathways used to obtain compounds 7-10 and 13-16 are reported in Scheme 2. Commercially available 4-amino-1-benzylpiperidine was treated with the proper acyl chloride or isopropylsulfonyl chloride; the intermediates $\mathbf{2 4},{ }^{18} \mathbf{2 5},{ }^{19} \mathbf{2 6}^{20}$ and $\mathbf{3 0}$ were then hydrogenated to give $\mathbf{2 7},{ }^{21} \mathbf{2 8},{ }^{22} \mathbf{2 9}^{23}$ and $\mathbf{3 1}$. Intermediates $\mathbf{2 7}$ and $\mathbf{2 8}$ were treated with 4-fluorobenzenesulfonyl chloride ${ }^{24}$ to give $\mathbf{9}$ and $\mathbf{1 0}$ and with isopropylsulfonyl chloride to give $\mathbf{1 3}$ and $\mathbf{1 4}$, whereas $\mathbf{2 9}$ was treated with acetyl or propionyl chloride to give 7 and 8. Finally, reaction of $\mathbf{3 1}$ with acetyl or propionyl chloride gave $\mathbf{1 5}$ and 16 respectively. Chemical and physical characteristics of compounds 5-16 are reported in Table 1.

Cognition enhancing activity was evaluated by the antiamnesic test (mouse passive-avoidance test). The test was performed according to the step-through method described by Jarvik and Kopp, ${ }^{25}$ slightly modified by us. ${ }^{4,26}$ In short, mice receive a punishment when entering a dark room in the training session and remember it in the session of the following day, unless their memory is impaired by the amnesic drug. The parameter measured is the entry latency time (expressed in seconds) occurring between the time the mouse is placed in the light and the time it enters the dark room. On the first day there is the training session, while on the second day the mice are placed again in the light and the new latency time is measured on animals treated or untreated with the nootropic drug. A drug is active when, at a given dose, it restores in the scopolaminetreated mice the retention time of those treated only with saline. The highest active doses of the investigated

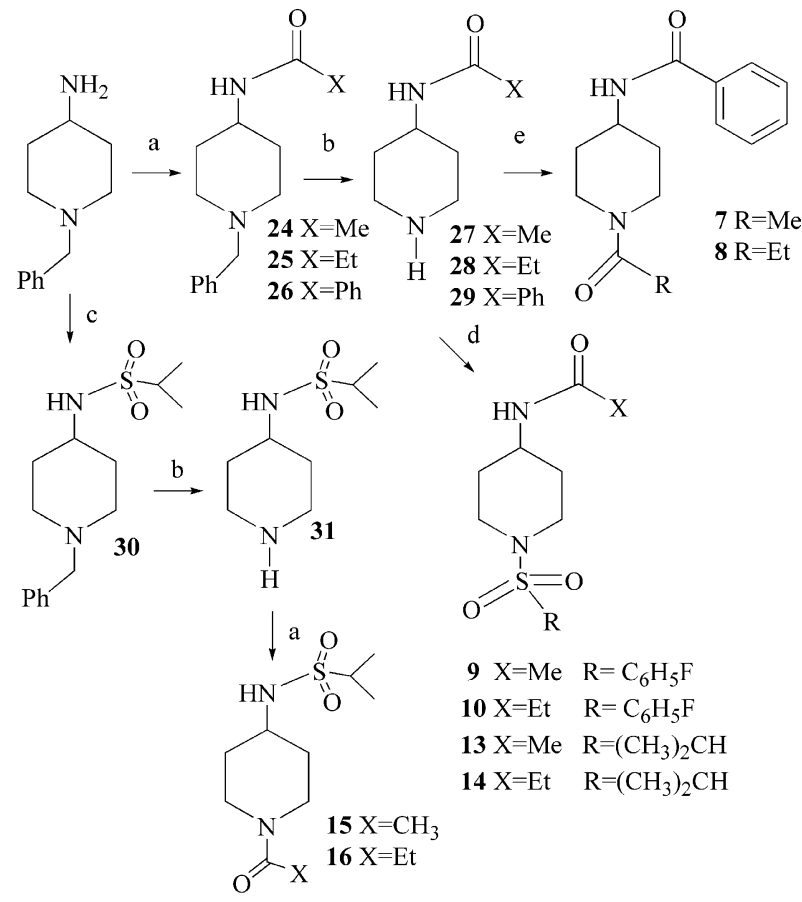

Scheme 2. (a) $\mathrm{XCOCl}, \mathrm{NaHCO}_{3}, \mathrm{CHCl}_{3}: \mathbf{2 4}, 79 \%, \mathbf{2 5}, 99 \%, \mathrm{NEt}_{3}$, $\mathrm{CHCl}_{3}: 26,99 \%, 15,55 \%, 16,42 \%$; (b) $\mathrm{HCOONH}_{4}, \mathrm{Pd} / \mathrm{C} 10 \%$, MeOH: 27, 98\%, 28, 73\%, 29, 88\%, 31, 50\%; (c) isopropylsulfonyl chloride, $\mathrm{N}(\mathrm{Et})_{3}, \mathrm{CH}_{3} \mathrm{CN}$ : 30, 57\%; (d) 4-F-benzenesulfonyl chloride or isopropylsulfonyl chloride, $\mathrm{N}(\mathrm{Et})_{3}, \mathrm{CH}_{3} \mathrm{CN}$ : 9, 59\%, 10, 84\%, 13 , $43 \%, 14,76 \%$; (e) XCOCl, $\mathrm{N}(\mathrm{Et})_{3}, \mathrm{CHCl}_{3}: \mathbf{7}, 47 \%, \mathbf{8}, 97 \%$. 
Table 1. Chemical and physical characteristics of compounds 5-16<smiles>[R7]NC1CCN([R2])CC1</smiles><smiles>CC(=O)c1ccccc1</smiles><smiles>CC(C)S(C)(=O)=O</smiles>

A B $\quad$ C

\begin{tabular}{lcccc}
\hline $\mathrm{N}$ & $\mathrm{R}_{1}$ & $\mathrm{R}_{2}$ & $\mathrm{Mp}\left({ }^{\circ} \mathrm{C}\right)^{\mathrm{a}}$ & Analysis ${ }^{\mathrm{b}}$ \\
\hline $\mathbf{5}$ & $\mathrm{COCH}_{3}$ & $\mathrm{~A}$ & $136-137$ & $\mathrm{C}_{14} \mathrm{H}_{18} \mathrm{~N}_{2} \mathrm{O}_{2}$ \\
$\mathbf{6}$ & $\mathrm{COC}_{2} \mathrm{H}_{5}$ & $\mathrm{~A}$ & $70-71$ & $\mathrm{C}_{15} \mathrm{H}_{20} \mathrm{~N}_{2} \mathrm{O}_{2}$ \\
$\mathbf{7}$ & $\mathrm{A}$ & $\mathrm{COCH}_{3}$ & $133-135$ & $\mathrm{C}_{14} \mathrm{H}_{18} \mathrm{~N}_{2} \mathrm{O}_{2}$ \\
$\mathbf{8}$ & $\mathrm{A}$ & $\mathrm{COC}_{2} \mathrm{H}_{5}$ & $107-108$ & $\mathrm{C}_{15} \mathrm{H}_{20} \mathrm{~N}_{2} \mathrm{O}_{2}$ \\
$\mathbf{9}$ & $\mathrm{COCH}_{3}$ & $\mathrm{~B}$ & $187-188$ & $\mathrm{C}_{13} \mathrm{H}_{17} \mathrm{FN}_{2} \mathrm{O}_{3} \mathrm{~S}$ \\
$\mathbf{1 0}$ & $\mathrm{COC}_{2} \mathrm{H}_{5}$ & $\mathrm{~B}$ & $162-163$ & $\mathrm{C}_{14} \mathrm{H}_{19} \mathrm{FN}_{2} \mathrm{O}_{3} \mathrm{~S}$ \\
$\mathbf{1 1}$ & $\mathrm{B}$ & $\mathrm{COCH}_{3}$ & $131-132$ & $\mathrm{C}_{13} \mathrm{H}_{17} \mathrm{FN}_{2} \mathrm{O}_{3} \mathrm{~S}$ \\
$\mathbf{1 2}$ & $\mathrm{B}$ & $\mathrm{COC}_{2} \mathrm{H}_{5}$ & $135-136$ & $\mathrm{C}_{14} \mathrm{H}_{19} \mathrm{FN}_{2} \mathrm{O}_{3} \mathrm{~S}$ \\
$\mathbf{1 3}$ & $\mathrm{COCH}_{3}$ & $\mathrm{C}$ & $90-91$ & $\mathrm{C}_{10} \mathrm{H}_{20} \mathrm{~N}_{2} \mathrm{O}_{3} \mathrm{~S}$ \\
$\mathbf{1 4}$ & $\mathrm{COC}_{2} \mathrm{H}_{5}$ & $\mathrm{C}$ & $85-86$ & $\mathrm{C}_{11} \mathrm{H}_{22} \mathrm{~N}_{2} \mathrm{O}_{3} \mathrm{~S}$ \\
$\mathbf{1 5}$ & $\mathrm{C}$ & $\mathrm{COCH}_{3}$ & $78-79$ & $\mathrm{C}_{10} \mathrm{H}_{20} \mathrm{~N}_{2} \mathrm{O}_{3} \mathrm{~S}$ \\
$\mathbf{1 6}$ & $\mathrm{C}$ & $\mathrm{COC}_{2} \mathrm{H}_{5}$ & $79-80$ & $\mathrm{C}_{11} \mathrm{H}_{22} \mathrm{~N}_{2} \mathrm{O}_{3} \mathrm{~S}$ \\
\hline
\end{tabular}

${ }^{a}$ All compounds crystallized from petrol ether.

${ }^{b}$ The analytical results are within $\pm 0.4 \%$ of the theoretical values. ${ }^{1} \mathrm{H}$ and ${ }^{13} \mathrm{C}$ NMR and IR spectra are consistent with the proposed structure. ${ }^{\mathrm{c}}$ This compound is among the ones claimed in a recent patent (see ref 17).

compounds did not altered animals' gross behaviour and were devoid of any behavioural side effect, as demonstrated by the Irwing test. ${ }^{27}$ The results obtained with the new molecules are reported in Table 2, compared with those of the parent compounds 1-4.

Table 2. Nootropic effect of compounds 1-4 and 5-16 on mouse passive avoidance test, using scopolamine (S) as amnesing drug

\begin{tabular}{|c|c|c|c|c|}
\hline \multirow{2}{*}{$\begin{array}{l}\text { Druga (number } \\
\text { of animals) }\end{array}$} & \multirow{2}{*}{$\begin{array}{c}\text { Minimal effective } \\
\text { dose } \mathrm{mg} / \mathrm{kg} \text { (ip) }\end{array}$} & \multicolumn{3}{|c|}{ Entry latency (s) } \\
\hline & & 1st day & 2nd day & $\Delta$ \\
\hline Saline (13) & - & $15.0 \pm 5.9$ & $95.6 \pm 8.8$ & 80.6 \\
\hline Scopolamine (6) & 1.5 & $16.6 \pm 4.7$ & $44.5 \pm 8.3^{*}$ & 27.9 \\
\hline $1^{\mathrm{b}}$ & 10 & & & \\
\hline $2(\mathrm{DM} 235)^{\mathrm{b}, \mathrm{c}}$ & $0.01-0.001$ & & & \\
\hline $3^{\mathrm{b}}$ & 0.01 & & & \\
\hline $4^{\mathrm{b}}$ & 0.01 & & & \\
\hline $5(18)$ & 10 & $12.8 \pm 4.5$ & $113.5 \pm 10.2^{* *}$ & 100.7 \\
\hline $6(7)$ & 0.1 & $18.0 \pm 4.7$ & $121.0 \pm 11.3^{* *}$ & 103.0 \\
\hline $7(11)$ & 1 & $16.5 \pm 3.7$ & $99.8 \pm 9.9 * *$ & 83.3 \\
\hline $8(7)$ & 0.1 & $19.7 \pm 5.3$ & $122.8 \pm 10.4^{* *}$ & 103.1 \\
\hline $9(9)$ & 0.01 & $14.5 \pm 3.8$ & $90.6 \pm 12.5^{* * *}$ & 76.1 \\
\hline $10(10)$ & 0.1 & $17.6 \pm 3.9$ & $103.4 \pm 9.5^{* *}$ & 85.8 \\
\hline $11(8)$ & 0.1 & $23.5 \pm 5.3$ & $126.8 \pm 13.8^{* *}$ & 92.6 \\
\hline $12(16)$ & 10 & $15.6 \pm 4.7$ & $108.2 \pm 8.4^{* *}$ & 103.0 \\
\hline $13(21)$ & 1 & $14.3 \pm 2.8$ & $89.7 \pm 8.5^{* * *}$ & 75.4 \\
\hline $14(19)$ & 10 & $14.2 \pm 3.5$ & $102.8 \pm 10.5^{* *}$ & 88.6 \\
\hline $15(18)$ & 10 & $15.1 \pm 3.7$ & $99.3 \pm 11.3^{* *}$ & 84.2 \\
\hline $16(16)$ & 10 & $14.5 \pm 3.2$ & $96.9 \pm 10.6^{* *}$ & 82.4 \\
\hline
\end{tabular}

$* P<0.01$ with respect to mice treated with saline. $* * P<0.01$; *** $P<0.05$ with respect to mice treated with scopolamine.

aAll compounds dissolved in saline.

${ }^{\mathrm{b}}$ See ref 9.

${ }^{\mathrm{c}}$ See ref 10
The data reported show that the new series of compounds maintains potent cognition enhancing activity, being effective at doses between 0.01 and $10 \mathrm{mg} / \mathrm{kg}$ ip, while a typical nootropic drug like piracetam, under the same conditions in experiments performed in parallel with our compounds, is active at a dose of $30 \mathrm{mg} / \mathrm{kg} \mathrm{ip} .^{8}$ In particular, compound 9 is active at a dose of $0.01 \mathrm{mg} /$ $\mathrm{kg}$ ip, which is in the same range of that of DM 235, the most potent among the parent compounds. ${ }^{8}$ Therefore, it may be concluded that transforming the piperazine moiety into a 4-aminopiperidine one does not alter the pharmacological behaviour of the original compounds. In the new series, the two nitrogen atoms are not equivalent and two regio-isomers are possible for each couple of substituents. Overall, the regio-isomers show similar potencies as cognition enhancers. In this respect, the isomers bearing the aromatic substituents on the piperidine nitrogen seem to be slightly more potent (compare 9/11, 10/12, 13/15) than their counterparts, even if the reverse is true for the couple 5/7 and the couples $6 / 8$ and $\mathbf{1 4} / \mathbf{1 6}$ show the same potency. Finally, the introduction of the isopropylsulfonic group did not produce remarkable results, even if compound $\mathbf{1 3}$ was found active at the dose of $1 \mathrm{mg} / \mathrm{kg}$ ip.

In conclusion, we have identified a new class of potent cognition enhancing drugs, among which compound 9 deserves further study and can be a useful new lead to develop drugs with cognition enhancing properties.

\section{Acknowledgements}

This research was financed with the funds of Italian Ministry of Instruction University and Research (MIUR).

\section{References and Notes}

1. Gualtieri, F.; Manetti, D.; Romanelli, M. N.; Ghelardini, C. Curr. Pharm. Des. 2002, 8, 125.

2. Parnetti, L.; Senin, U.; Mecocci, P. Drugs 1997, 53, 752.

3. Hirai, S. Alz. Dis. Ass. Dis. 2000, 14, S11.

4. Manetti, D.; Ghelardini, C.; Bartolini, A.; Bellucci, C.; Dei, S.; Galeotti, N.; Gualtieri, F.; Romanelli, M. N.; Scapecchi, S.; Teodori, E. J. Med. Chem. 2000, 43, 1969.

5. Froestl, W.; Maitre, L. Pharmacopsychiatry 1989, 22, 54.

6. Gouliaev, A. H.; Binau Moster, J.; Vedso, M.; Senning, A. Org. Prep. Proceed. Int. 1995, 27, 273.

7. Gouliaev, A. H.; Senning, A. Brain Res. Rev. 1994, 19, 180. 8. Manetti, D.; Ghelardini, C.; Bartolini, A.; Dei, S.; Galeotti, N.; Gualtieri, F.; Romanelli, M. N.; Teodori, E. J. Med. Chem. 2000, 43, 4499.

9. Ghelardini, C.; Galeotti, N.; Gualtieri, F.; Manetti, D.; Bucherelli, C.; Baldi, E.; Bartolini, A. Drug Dev. Res. 2002, 56, 23.

10. Ghelardini, C.; Galeotti, N.; Gualtieri, F.; Romanelli, M. N.; Bucherelli, C.; Baldi, E.; Bartolini, A. N.S. Arch. Pharmacol. 2002, 365, 419.

11. Ornstein, P. L.; Zimmerman, D. M.; Arnold, M. B.; Bleisch, T. S.; Cantrell, B.; Simon, R.; Zarrinmayeh, H.; Baker, S. R.; Gates, M.; Tizzano, J. P.; Bleakman, D. J. Med. Chem. 2000, 43, 4354. 
12. Zarrinmayeh, H.; Bleakman, D.; Gates, M.; Yu, H.; Zimmerman, D. M.; Ornstein, P. L.; McKennon, T.; Arnold, M. B.; Wheeler, W. J.; Skolnick, P. J. Med. Chem. 2001, 44, 302.

13. Mattson, R. J.; Pham, H. M.; Lenck, D. J.; Cowen, K. A. J. Org. Chem. 1990, 55, 2552.

14. ElAim, B.; Anantharanaiah, G. M.; Royer, G. P.; Means, G. E. J. Org. Chem. 1979, 44, 3442.

15. Bhattacharayya, S.; Neidigh, K. A.; Avery, M. A.; Williamson, J. S. Syn. Lett. EN 1999, 11, 1781.

16. Suedo, N. Eur. Pat. Appl. EP 625,507, 1994.

17. Yamada, A.; Aoki, S. PCT Int. Appl. WO 0,042,011, 2000.

18. Archibald, J.; Fairbrother, P.; Jackson, J. L. J. Med. Chem. 1974, 17, 739.

19. Peglion, J. L.; Colpaert, F. Eur. Pat. Appl. EP 457,686, 1991.

20. Harper, N.; Chignell, C. F. J. Med. Chem. 1964, 7, 729.

21. Zenitz, B. L. US 3,124,586,1964; Chem Abst. 1964, 61, 18188.

22. Schnorrenberg, G.; Dollinger, H.; Esser, F.; Brien, H.; Jung, B.; Speck, G. Gen. Offen. DE 19,519,245, 1996.

23. Archibald, J. L.; Alps, B. J.; Cavalla, J. F.; Jackson, J. L. J. Med. Chem. 1971, 14, 1054.
24. Stetter, H.; Reinartz, W. Chem. Ber. 1972, 105, 2773.

25. Jarvik, M. E.; Kopp, R. Psycol. Rep. 1967, 21, 221.

26. The apparatus for the passive avoidance test consists of a two-compartment acrylic box with a lighted compartment connected to a darkened one by a guillotine door. In the original method, mice received a punishing electrical shock as soon as they entered the dark compartment, while in our modified method, after entry into the dark compartment, mice receive a non-painful punishment consisting of a fall (from $40 \mathrm{~cm})$ into a cold water bath $\left(10^{\circ} \mathrm{C}\right)$. For this purpose, the dark chamber was constructed with a pitfall floor. The latency times for entering the dark compartment were measured in the training test (first day) and after $24 \mathrm{~h}$ in the retention test (second day). Mice who did not enter after $60 \mathrm{~s}$ latency were excluded from the experiment. For memory disruption, mice were ip injected with the amnesic drug scopolamine. All investigated drugs, dissolved in saline, were given ip $20 \mathrm{~min}$ before the training session, while amnesic drug was injected immediately after termination of the training session. The maximum entry latency allowed in the retention session was $120 \mathrm{~s}$. The degree of received punishment memory (fall into cold water) was expressed as the increase in seconds between training and retention latencies.

27. Irwing, S. Psychopharmacology 1966, 13, 222. 